Research paper

\title{
Sustainable use of eucalypt biomass grown on short rotation coppice for bioenergy
}

\author{
Humbertode Jesus Eufrade Junior ${ }^{a}$, , Raoni Xavier de Melo ${ }^{\mathrm{b}}$, \\ Maria Márcia Pereira Sartori c, Saulo Philipe Sebastião Guerra b, Adriano Wagner Ballarin ${ }^{\text {a }}$ \\ a Department of Rural Engineering, College of Agricultural Sciences, Sao Paulo State University, Botucatu 18610307, Brazil \\ b Department of Economy, Sociology and Technology Department, College of Agricultural Sciences, Sao Paulo State University, Botucatu 18610307, Brazil \\ ${ }^{c}$ Department of Crop Science, College of Agricultural Sciences, Sao Paulo State University, Botucatu 18610307, Brazil
}

\section{A R T I C L E I N F O}

\section{Article history:}

Received 21 July 2015

Received in revised form

2 March 2016

Accepted 24 March 2016

Available online 1 April 2016

\section{Keywords:}

Forest biomass

Short rotation woody crops

Dry matter

Energy yield

Nutrients export

\begin{abstract}
A B S T R A C T
Bioenergy is one of the alternatives to reduce the dependence of global energy on fossil fuels. The short rotation coppice (SRC) of eucalypt species appears as an interesting option for forest biomass production in a short time. However, the harvesting of whole trees (included the crown) in SRC systems has implications on sustainable land use. More information is required on the increase of biomass as renewable energy resource to achieve the sustainability of these crops. The main objective of this research was to evaluate the sustainable use of biomass from very high-density eucalypt plantations, managed at tropical conditions for bioenergy. To accomplish this objective, the tree was fractionated into three fractions: stem, branches, and leaves, and there was determination of the dry matter, energy yield, and nutrients export. This experiment used a short rotation coppice, a hybrid clone of Eucalyptus urophylla $\times$ Eucalyptus grandis, of 2 years old. According to the results obtained, the density planting and fertilization levels have a greater influence on the dry matter yield, energy yield, and nutrient exports. The higher density planting reaches mean values of 30.9 tonnes of dry matter per hectare $\left(\mathrm{t} \mathrm{DM} \mathrm{ha}{ }^{-1}\right)$ and $743.3 \mathrm{GJ} \mathrm{ha}^{-1}$. Considering the biomass yield and nutrients export of short rotation coppice of eucalypt, the higher density planting with the lower dose of fertilization is more indicative of sustainable use. The leaves have an important participation in nutrients export and should be retained in the soil of forest.
\end{abstract}

๑) 2016 Elsevier Ltd. All rights reserved.

\section{Introduction}

Biomass resources will be one of the most important factors for environmental protection in the 21st century [1]. Actually, biomass accounted for about $10 \%$ of global primary energy supply (estimated 56.6 EJ) according REN [2] and studies suggest that biomass will continue to increase by 2050 [3].

Some agricultural and forest species have greater potential for providing biomass to energy; these species are called energy crops and they must meet certain conditions, such as adaptation to the environment in which they are growing, with resistance to pathogens and climate, among others and good features as an energy source $[4,5]$.

Short rotation woody crops differ from conventional forestry in a number of aspects. Management of the trees is conducted with

\footnotetext{
* Corresponding author.

E-mail address: hdjejunior@gmail.com (H.J. Eufrade Junior).
}

high planting density and intensive silvicultural treatments (weeding, fertilizing, and irrigating) and these management methods respond with very rapid growth [6]. The main species used worldwide in the production of forest biomass for energy purposes are as follows: eucalypt (Eucalyptus), willow (Salix), and poplar (Populus). Other alternatives, such as Paulownia and Robinia, are also increasing, especially in Europe. Table 1 presents the productivity of these species in different parts of the world.

In Brazil, the eucalypt is the most important forest species for wood supply, occupies an area of 5.56 million hectares [16], and the average stem wood productivity is about $25 \mathrm{t} \mathrm{DM} \mathrm{ha}^{-1}$ year $^{-1}$ for conventional silviculture [17]. Recently, there was testing of this species to high-density planting and it reached double productivity, becoming an important option for energy generation [18].

During the harvesting of short rotation coppice (SRC), all aboveground biomass (stem, branches, and leaves) was chipped and used for energy, and not debarked stems, as in conventional plantations [19]. When compared to the traditional system, the 
Table 1

Biomass production of dedicated energy crops around the world.

\begin{tabular}{|c|c|c|c|c|c|}
\hline Espécie & Dry matter yield (t DM ha ${ }^{-1}$ year $^{-1}$ ) & Rotation (years) & Planting density (trees ha ${ }^{-1}$ ) & Countries & Ref. \\
\hline Eucalyptus bridgesiana & 6.5 & 2 & 6,667 & Italy & [7] \\
\hline Eucalyptus spp. & 14.1 & 3 & 4,167 & New Zealand & [8] \\
\hline Eucalyptus globulus & 5.3 & 3 & 4,000 & Australia & [9] \\
\hline Eucalyptus occidentalis & 7.3 & 3 & 4,000 & Australia & [9] \\
\hline Eucalyptus grandis & 16.0 & 3.5 & 3,400 & EUA & [10] \\
\hline Eucalytpus amplifolia & 17.8 & 3.5 & 3,400 & EUA & {$[10]$} \\
\hline Populus alba & 5.4 & 3 & 1,111 & Italy & [11] \\
\hline Populus spp. & 10.6 & 2 & 5,900 & Italy & {$[12]$} \\
\hline Salix spp. & 10.6 & 3 & 1,111 & Italy & [11] \\
\hline Salix spp. & 4.2 & 4 & 12,000 & Sweden & [13] \\
\hline Paulownia sp. & 5.3 & 2 & 1,650 & Spain & {$[14]$} \\
\hline Robinia pseudoacacia & 3.0 & 4 & 9,200 & Sweden & {$[15]$} \\
\hline
\end{tabular}

harvesting of SRC has fewer steps, and the use of forage harvester avoids the stationary chipping terminal, preventing additional costs with other machines and equipment (Fig. 1).

The harvest of whole tree in SRC of eucalypt highlights an environmental issue. Instead, what happens with other species (as poplars and willow) in temperate climate, some eucalyptus do not shed their leaves in the dry season, and this has direct implications on sustainable land use, due to the greatest macro- and micronutrients content in the leaves and bark [21,22].

More information about the increase of biomass as renewable energy resource is required to achieve the sustainability of SRC. Thus, the design and management of very high-density forests should focus not only on the energy and biomass yield, but also on the nutrients export. So, preferably, it must be a used species or clones of rapid growth, with high performance and high efficiency in the use of nutrients $[8,23]$.

To evaluate the sustainable use of SRC of eucalypt for bioenergy, the tree was analyzed in three fractions: stem (wood and bark), branches, and leaves. Therefore, the goals of this study were: (1) to determine the biomass and energy yields of the very high-density energy plantations, gaging the effect of different spacing and fertilization regimes; (2) to estimate the nutrients export under these same conditions; and (3) to evaluate the sustainability of whole tree use as efficient energy crops.

\section{Materials and methods}

This work was carried out in Botucatu city $\left(22^{\circ} 53^{\prime} 09^{\prime \prime} \mathrm{S}\right.$ and $48^{\circ} 26^{\prime} 42^{\prime \prime} \mathrm{W}$ ) located at São Paulo state in Brazil. The local area has an average altitude of $872 \mathrm{~m}$, a mean annual precipitation of about $1428 \mathrm{~mm}_{\text {year }}{ }^{-1}$, and an annual average temperature of $20^{\circ} \mathrm{C}$.

Management of the plantations of interspecific hybrid clone, Eucalyptus urophylla $\times$ Eucalyptus grandis, at 2 years old was with distinct conditions of higher planting density and fertilization. All plots were established at two different spacing modules: $2.8 \times 0.5 \mathrm{~m}\left(7142\right.$ trees hectare $\left.{ }^{-1}\right)$ and $2.8 \times 1.5 \mathrm{~m}(2380$ trees hectare $\left.^{-1}\right)$; and Table 2 describes two different fertilization regimes (dose 1 and dose 2).

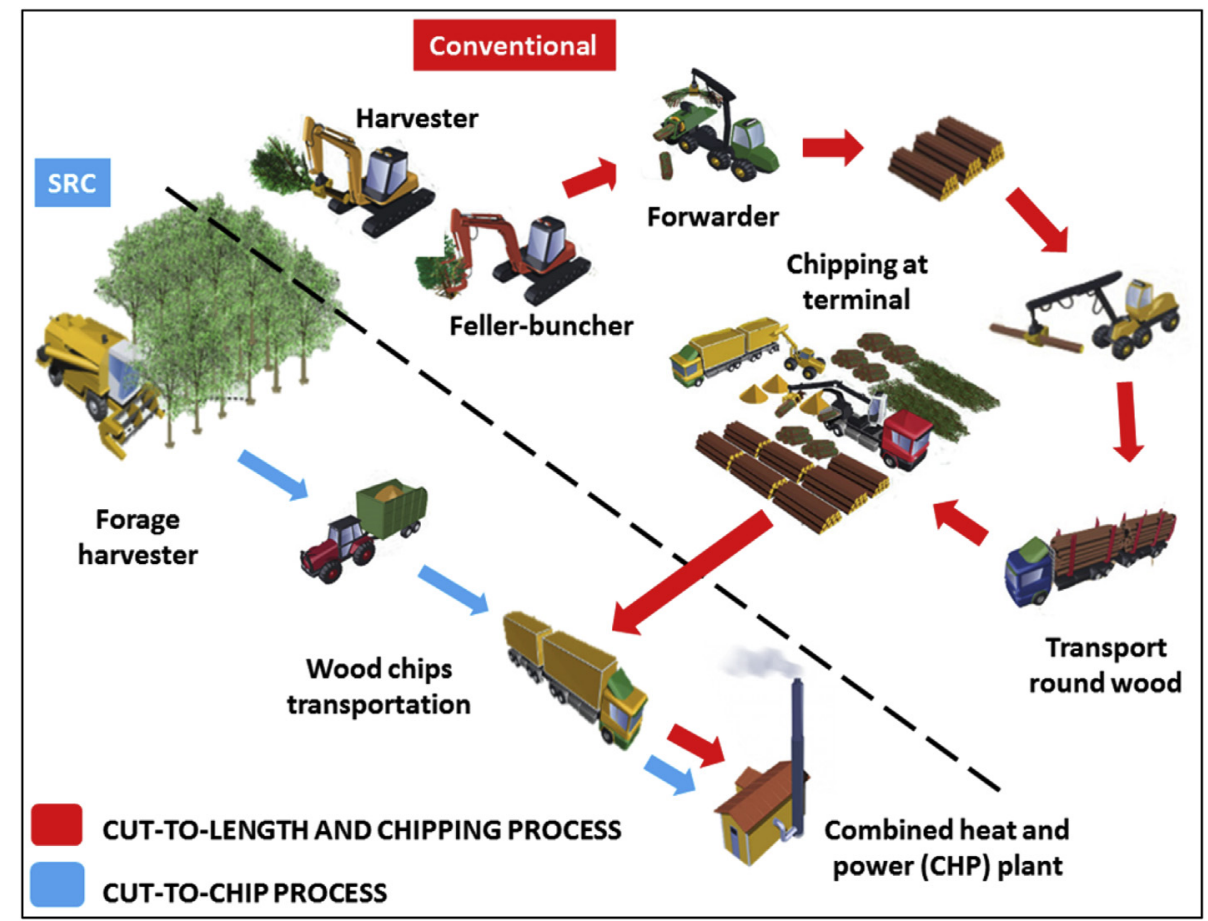

Fig. 1. Comparation between shot rotation coppice and conventional harvesting systems. Forest Energy Portal [20] modified by author. 
Table 2

Description of the fertilization regimes.

\begin{tabular}{lllll}
\hline Fertilizing levels & & 1 & \multicolumn{2}{c}{2} \\
\cline { 1 - 2 } Fertilizer & & Days after planting & \multicolumn{2}{c}{ g plant $^{-1}$} \\
\hline NPK (6-30-10) & 0 & 35.0 & 140 \\
NPK $(19-00-19)+$ B $(0,7 \%)$ e Zn (3\%) & 180 & 27.5 & 110 \\
NPK (19-00-19) + B (0,7\%) e Zn (3\%) & 360 & 27.5 & 110 \\
\hline
\end{tabular}

Fertilizing level 1 corresponds to one-quarter of the level 2 (conventional level).

Due to the similarity of the local site conditions, installation of the experiment was with a completely randomized design. A central plot of $450 \mathrm{~m}^{2}$ was used per treatment and the experimental design was 2 spacing density $\times 2$ fertilization regimes $\times 3$ biomass fractions $\times 5$ repetitions.

Two years after planting, there was measurement of the diameter at breast height (DBH) and height of all trees on plot and selection of four mean tree samples randomly per treatment.

The tree was divided in three fractions: stem, branches, and leaves, and a composite sample was used to each biomass fraction. The branches and leaves of trees were separated and weighed at field. Then, there was collection of five discs at the following positions along the stem: $0 \%, 25 \%, 50 \%, 75 \%$, and $100 \%$ of total stem height according to the method described by Vital [24]. The basic densities of discs were obtained through the ratio between the dry mass and saturated volume of the specimens, and indirectly the dry matter of stem. Afterward, the moisture content - ASTM E871-82 [25], heating value - ASTM E711-87 [26], and macro- and micronutrients - Malavolta et al. [27] - of composite samples were determined in the laboratory. These properties were combined with dry mass production in order to estimate total energy yield and nutrients export.

To evaluate the more sustainable condition, there was usage of the Nutrient Assimilation Index (NAI) proposed by Sochaki et al. [9] and it applied only the macronutrients for each treatment and biomass fraction (Eq. (1)),

$\mathrm{NAI}=\frac{\mathrm{Bc}}{\mathrm{Nc}}$

where, NAI is the nutrient assimilation index $\left(\mathrm{t} \mathrm{DM} \mathrm{kg}^{-1}\right), \mathrm{Bc}$ is dry matter yield per treatment or biomass fraction $\left(\mathrm{t} \mathrm{DM} \mathrm{ha}{ }^{-1}\right)$, and $\mathrm{Nc}$ is the component nutrients assimilated per treatment or biomass fraction $\left(\mathrm{kg} \mathrm{ha}^{-1}\right)$. Larger values indicated a good nutrient use efficiency and lower values indicated poorly performing treatment.

In the statistical analysis, the data normality was assessed by Shapiro-Wilk's test $(p<0.05)$. The effect of treatments in the biomass properties, dry matter yield, energy yield, and nutrients export were evaluated by analysis of variance (ANOVA), complemented by Tukey's test (significant at $p<0.05$ ). Basic statistics (central tendency and dispersion) was used to analyze the Nutrient Assimilation Index (NAI).

\section{Results and discussion}

\subsection{Silvicultural parameters}

The spacing and fertilization studied have more effect on the diameter breast than height (Table 3). Bernardo et al. [28], while also studying eucalypt, presented that individual trees responded to wider spacing and lower competition with greater individual diameter growth.

There is similarity of both silvicultural parameters with other studies of fast-growing eucalypt forest plantations [10,29].

It was found the major values of increment of wood for higher density planting according to recent studies that report the increase of wood production with rise in the number of trees per hectare [30]. These values reaffirm the potential of eucalypt to supply the biomass demand for energy, by avoiding the use of native forest [31].

The MAI was similar in the higher density planting and fertilization levels did not influence, suggesting new studies about the ideal amount of fertilizer in efficient energy crops.

\subsection{Biomass properties}

Table 4 shows that all properties are statistically different only for biomass fractions (stem, branches, and leaves). In this table, small letters $(a, b, c)$ represent the effect of stem, branches, and leaves mass fractions, and capital letters $(A, B, C, D)$ represent the effect of spacing and fertilization regimes.

The leaves had the major values of higher heating value compared with woody fractions, probably due to the high values of carbon and hydrogen, and extractive content [32].

The moisture content of biomass is higher than that recommended for direct combustion (less than or equal to 30\%), as reported by Garstang et al. [33]. Hence, the forest biomass should be stored or dried before use, increasing the energy efficiency of biomass [34].

Although the basic density increase due to fertilizing levels did not occur statistically difference, these results were similar to those from Eloy [35], who also studied energy crops of Eucalyptus spp. and other forest species in Brazil.

Despite the spacing planting and fertilizing levels tested, all biomass properties were similar statistically. Some authors report that the most significant differences of properties are more associated with age of tree than conditions of management as fertilization and density stand [18,36,37].

\subsection{Dry matter and energy yield}

Due to similar results of heating value and basic density found, Table 5 shows the major values of dry matter suggesting more energy production.

The higher density planting had more dry matter allocation in the stem than lower density planting. More light availability in lower density stand, contributing to grown of crown, explains this.

The dry matter of stem per tree was greater in the major level of

Table 3

Silvicultural parameters of Eucalyptus grandis $\times$ E. urophylla, at 2 years old.

\begin{tabular}{|c|c|c|c|c|}
\hline Spacing $(\mathrm{m})$ & Fert. levels & Height $(\mathrm{m})$ & Diameter breast height $(\mathrm{cm})$ & Mean annual increment $\left(\mathrm{m}^{3} \mathrm{ha}^{-1}\right.$ year $\left.^{-1}\right)$ \\
\hline $2.8 \times 0.5$ & 1 & $10.9 \pm 1.6 \mathrm{~A}$ & $5.8 \pm 1.3 \mathrm{C}$ & $40.7 \pm 3.7 \mathrm{~A}$ \\
\hline $2.8 \times 0.5$ & 2 & $9.7 \pm 1.3 \mathrm{~B}$ & $6.6 \pm 1.7 \mathrm{C}$ & $41.7 \pm 3.6 \mathrm{~A}$ \\
\hline $2.8 \times 1.5$ & 1 & $9.5 \pm 0.9 \mathrm{~B}$ & $7.0 \pm 1.2 \mathrm{~B}$ & $19.5 \pm 3.7 \mathrm{C}$ \\
\hline $2.8 \times 1.5$ & 2 & $10.7 \pm 1.4 \mathrm{~A}$ & $8.3 \pm 1.3 \mathrm{~A}$ & $28.5 \pm 2.2 \mathrm{~B}$ \\
\hline
\end{tabular}

The means that do not differ from each other at the 0.05 significance level by Tukey's test are marked with the same letters. 
Table 4

Biomass properties of Eucalyptus grandis $\times$ E. urophylla, at 2 years old.

\begin{tabular}{|c|c|c|c|c|c|c|c|c|}
\hline \multirow[t]{2}{*}{ Spacing (m) } & \multirow[t]{2}{*}{ Fert. levels } & \multicolumn{3}{|c|}{ Higher heating value $\left(\mathrm{MJ} \mathrm{kg}^{-1}\right)$} & \multicolumn{3}{|c|}{ Moisture content (\%) } & \multirow{2}{*}{$\frac{\text { Basic density }\left(\mathrm{kg} \mathrm{m}^{-3}\right)}{\text { Stem }}$} \\
\hline & & Stem & Branches & Leaves & Stem & Branches & Leaves & \\
\hline $2.8 \times 0.5$ & 1 & $18.6 \pm 0.3 \mathrm{~A}$ & $19.3 \pm 0.2 \mathrm{~A}$ & $22.2 \pm 0.1 \mathrm{~A}$ & $65.3 \pm 0.9 \mathrm{~A}$ & $44.9 \pm 6.0 \mathrm{~A}$ & $61.5 \pm 1.0 \mathrm{~A}$ & $354.5 \pm 7.90 \mathrm{~A}$ \\
\hline $2.8 \times 0.5$ & 2 & $18.9 \pm 0.1 \mathrm{~A}$ & $19.2 \pm 0.3 \mathrm{~A}$ & $21.9 \pm 0.1 \mathrm{~A}$ & $63.5 \pm 1.0 \mathrm{~A}$ & $46.8 \pm 9.7 \mathrm{~A}$ & $57.0 \pm 1.2 \mathrm{~A}$ & $370.7 \pm 14.0 \mathrm{~A}$ \\
\hline $2.8 \times 1.5$ & 1 & $19.1 \pm 0.2 \mathrm{~A}$ & $19.1 \pm 0.1 \mathrm{~A}$ & $21.8 \pm 0.1 \mathrm{~A}$ & $64.5 \pm 1.4 \mathrm{~A}$ & $52.1 \pm 2.8 \mathrm{~A}$ & $54.9 \pm 5.1 \mathrm{~A}$ & $368.8 \pm 22.4 \mathrm{~A}$ \\
\hline $2.8 \times 1.5$ & 2 & $19.0 \pm 0.2 \mathrm{~A}$ & $19.3 \pm 0.4 \mathrm{~A}$ & $22.2 \pm 0.1 \mathrm{~A}$ & $62.7 \pm 1.2 \mathrm{~A}$ & $52.8 \pm 1.5 \mathrm{~A}$ & $58.7 \pm 0.4 \mathrm{~A}$ & $381.6 \pm 11.4 \mathrm{~A}$ \\
\hline \multicolumn{2}{|c|}{ Arithmetic mean } & $18.9 \pm 0.3 c$ & $19.2 \pm 0.3 b$ & $22.0 \pm 0.2 \mathrm{a}$ & $64.0 \pm 1.4 \mathrm{a}$ & $49.2 \pm 6.3 c$ & $58.0 \pm 3.5 b$ & $368.9 \pm 16.6$ \\
\hline
\end{tabular}

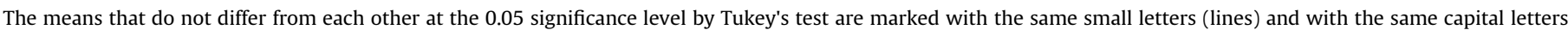
(column).

Table 5

Tree size, biomass yield, tree energy content and energy yield for Eucalyptus grandis $\times$ E. urophylla, at 2 years old, depending on the spacing, fertilization rate and biomass fraction.

\begin{tabular}{|c|c|c|c|c|}
\hline \multirow[t]{2}{*}{ Spacing $(\mathrm{m})$} & \multirow[t]{2}{*}{ Fert. levels } & \multicolumn{3}{|l|}{ Biomass fractions } \\
\hline & & Stem & Branches & Leaves \\
\hline \multicolumn{5}{|c|}{ kg per tree (dry matter) } \\
\hline $2.8 \times 0.5$ & 1 & $5.4 \pm 0.4 \mathrm{Da}$ & $1.2 \pm 0.2 \mathrm{Ab}$ & $0.6 \pm 0.1 \mathrm{Bb}$ \\
\hline $2.8 \times 0.5$ & 2 & $8.7 \pm 0.8 \mathrm{Ba}$ & $1.3 \pm 0.3 \mathrm{Ab}$ & $1.1 \pm 0.1 \mathrm{ABb}$ \\
\hline $2.8 \times 1.5$ & 1 & $7.2 \pm 1.1 \mathrm{Ca}$ & $1.7 \pm 0.4 \mathrm{Ab}$ & $2.1 \pm 0.5 \mathrm{Ab}$ \\
\hline $2.8 \times 1.5$ & 2 & $12.9 \pm 1.2 \mathrm{Aa}$ & $2.3 \pm 0.4 \mathrm{Ab}$ & $2.5 \pm 0.3 \mathrm{Ab}$ \\
\hline \multicolumn{5}{|c|}{ tonnes per hectare (dry matter) } \\
\hline $2.8 \times 0.5$ & 1 & $28.9 \pm 2.6 \mathrm{Aa}$ & $6.1 \pm 0.5 \mathrm{Ab}$ & $3.1 \pm 0.3 \mathrm{Ab}$ \\
\hline $2.8 \times 0.5$ & 2 & $30.9 \pm 2.7 \mathrm{Aa}$ & $4.6 \pm 0.4 \mathrm{Ab}$ & $4.1 \pm 0.4 \mathrm{Ab}$ \\
\hline $2.8 \times 1.5$ & 1 & $14.4 \pm 2.7 \mathrm{Ca}$ & $3.4 \pm 0.6 \mathrm{Ab}$ & $4.1 \pm 0.8 \mathrm{Ab}$ \\
\hline $2.8 \times 1.5$ & 2 & $21.7 \pm 1.7 \mathrm{Ba}$ & $3.8 \pm 0.3 \mathrm{Ab}$ & $4.2 \pm 0.3 \mathrm{Ab}$ \\
\hline \multicolumn{5}{|l|}{ MJ per tree } \\
\hline $2.8 \times 0.5$ & 1 & $100.5 \pm 8.3 \mathrm{Ca}$ & $22.2 \pm 3.8 \mathrm{Ab}$ & $13.0 \pm 1.0 \mathrm{Cb}$ \\
\hline $2.8 \times 0.5$ & 2 & $164.3 \pm 14.6 \mathrm{Ba}$ & $24.9 \pm 5.4 \mathrm{Ab}$ & $24.9 \pm 2.9 \mathrm{BCb}$ \\
\hline $2.8 \times 1.5$ & 1 & $136.8 \pm 20.0 \mathrm{Ba}$ & $39.5 \pm 8.7 \mathrm{Ab}$ & $45.1 \pm 9.9 \mathrm{ABb}$ \\
\hline $2.8 \times 1.5$ & 2 & $244.8 \pm 22.0 \mathrm{Aa}$ & $44.0 \pm 7.4 \mathrm{Ab}$ & $54.9 \pm 7.2 \mathrm{Ab}$ \\
\hline \multicolumn{5}{|l|}{ GJ per hectare } \\
\hline $2.8 \times 0.5$ & 1 & $536.1 \pm 48.2 \mathrm{Aa}$ & $117.9 \pm 10.6 \mathrm{Ab}$ & $69.7 \pm 6.3 \mathrm{Ab}$ \\
\hline $2.8 \times 0.5$ & 2 & $584.7 \pm 51.0 \mathrm{Aa}$ & $88.8 \pm 7.7 \mathrm{Ab}$ & $89.4 \pm 7.8 \mathrm{Ab}$ \\
\hline $2.8 \times 1.5$ & 1 & $273.9 \pm 52.3 \mathrm{Ca}$ & $64.0 \pm 12.2 \mathrm{Ab}$ & $89.7 \pm 17.1 \mathrm{Ab}$ \\
\hline $2.8 \times 1.5$ & 2 & $414.1 \pm 31.9 \mathrm{Ba}$ & $74.1 \pm 5.7 \mathrm{Ab}$ & $92.6 \pm 7.1 \mathrm{Ab}$ \\
\hline
\end{tabular}

The means that do not differ from each other at the 0.05 significance level by Tukey's test are marked with the same small letters (lines) and with the same capital letters (column).

fertilization and wider spacing. The dry matter of branches per tree did not vary according to the treatments, but we observed lower values of leaves in the higher density planting and lower dose of fertilizer. It is important highlight that biomass allocation on tree was found just for the first rotation of SRC studied, and it can be variable for further rotations and other species.

There is acceptance that wider spacing causes a lower total biomass production per area, but with higher biomass per tree [38], corroborating with results found. The same trend occurred to energy yield.

In Brazil, SRC of eucalypt species can reach values greater than $17 \mathrm{t} \mathrm{DM} \mathrm{ha}^{-1}$ until $50 \mathrm{t} \mathrm{DM} \mathrm{ha}^{-1}$ in cycles of one year with excellent condition management [18]. These values were similar to those obtained in this study and were greater than other species as poplar and willow, traditionally used for energy [11,12], also demonstrating high potential biomass carbon sequestration [39].

The greater fertilizing level did not significantly produce more dry matter in the higher density planting, suggesting the amount of lowest dose fertilizer applied per tree was sufficient to reach the nutritional demand.

Greater values of energy yield were determined for stem fraction. The leaves and branches were statistically equal and accounted about $14 \%$ of energy yield each, representing one-third of energy yield.
Other results show that total energy yield (sum of three biomass fractions) was statistically different by level of fertilizing (575.7 GJ ha ${ }^{-1}$ to dose 1 and $671.9 \mathrm{GJ} \mathrm{ha}^{-1}$ to dose 2 ) and spacing planting $\left(743.3 \mathrm{GJ} \mathrm{ha}^{-1}\right.$ to $2.8 \times 0.5 \mathrm{~m}$ and $504.2 \mathrm{GJ} \mathrm{ha}^{-1}$ to $2.8 \times 1.5 \mathrm{~m})$.

Tropical countries have a great potential to use biomass energy from forest plantations. The energy yield obtained was higher than efficient energy eucalypt forest in Europe [4] and other species, such as willow and poplar, 187-280 GJ ha ${ }^{-1}$ and 173-259 GJ ha ${ }^{-1}$, respectively [40].

\subsection{Nutrients export}

The stem is responsible for greater exports of macro- and micronutrients per hectare (Table 6). However, even representing a little part of dry matter, the leaves have a very important role in the export of nitrogen, phosphorus, boron, and magnesium. Overall, the major nutrients content was found in the leaves, after woody fractions. Only copper nutrient content was similar statistically for all fractions.

The contribution to the content of nutrients in different fractions was generally in the order: leaves $>$ branches $>$ stem (wood and bark). When it was analyzed all aboveground biomass, the order was reversed: stem (wood and bark) > leaves > branches. However, these orders can vary according to nutrient analyzed.

The leaves and branches have an important contribution to litter accumulation, nutrient cycle, and soil fertility. This effect can be more significant in tropical soils due to fast decomposition of organic matter. Achat [21] discussed that removing foliage strongly increases nutrient outputs, while the gain in harvested biomass is low.

Analyzing between treatments and considering all biomass, in general, it was obtained higher values of nutrients export by higher spacing density and greater fertilizing level, as shown in Table 7.

The nutrients export of the lower density planting $(2.8 \times 1.5 \mathrm{~m})$ and fertilizing level 2 was similar to higher density planting $(2.8 \times 0.5 \mathrm{~m})$ and fertilizing level 1 , except for $\mathrm{K}$ and Ca nutrients. This can be explained by the fact that both treatments had statistically equal dry matter yield of leaves and branches.

The all-aboveground nutrients export was found in ascending order as follows: $\mathrm{P}>\mathrm{Mg}>\mathrm{S}>\mathrm{N}>\mathrm{K}>\mathrm{Ca}$ (macronutrients) and $\mathrm{Cu}>\mathrm{Zn}>\mathrm{B}>\mathrm{Mn} \geq \mathrm{Fe}$ (micronutrients). The greater calcium and potassium exports can be assigned to stem, and nitrogen to leaves fraction.

It is known that nutrients export in fast-growing forest plantations can be reduced through the selection of suitable tree species, lowering the planting density, increasing the length of the rotation, and reducing the intensity of harvesting [23,41]. However, new design of forest management and studies in a more detailed manner about nutrients exports are essential to arrange the fast biomass yield and lower environmental impact. 
Table 6

Arithmetic mean nutrients export per biomass fraction of Eucalyptus grandis $\times$ E. urophylla, at 2 years old.

\begin{tabular}{|c|c|c|c|c|c|c|}
\hline \multirow[t]{2}{*}{ Nutrients } & \multicolumn{3}{|l|}{$\mathrm{g} \mathrm{kg}^{-1}$} & \multicolumn{3}{|l|}{$\mathrm{Kg} \mathrm{ha}^{-1}$} \\
\hline & Stem & Branches & Leaves & Stem & Branches & Leaves \\
\hline $\mathrm{N}$ & $1.35 \pm 0.11 c$ & $2.58 \pm 0.36 b$ & $18.21 \pm 2.11 \mathrm{a}$ & $32.80 \pm 12.15 c$ & $11.70 \pm 3.92 b$ & $70.09 \pm 7.22 \mathrm{a}$ \\
\hline $\mathrm{P}$ & $0.15 \pm 0.01 c$ & $0.28 \pm 0.05 b$ & $0.92 \pm 0.07 \mathrm{a}$ & $3.77 \pm 1.42 \mathrm{a}$ & $1.28 \pm 0.41 b$ & $3.56 \pm 0.35 a$ \\
\hline K & $3.01 \pm 0.65 c$ & $4.09 \pm 0.95 b$ & $5.96 \pm 0.67 \mathrm{a}$ & $75.51 \pm 37.33 a$ & $18.87 \pm 7.97 \mathrm{c}$ & $23.00 \pm 3.07 b$ \\
\hline $\mathrm{Ca}$ & $4.87 \pm 0.46 b$ & $7.1 \pm 0.56 \mathrm{a}$ & $6.83 \pm 1.31 \mathrm{a}$ & $117.77 \pm 43.79 a$ & $31.39 \pm 6.29 b$ & $26.7 \pm 7.22 b$ \\
\hline Mg & $0.58 \pm 0.06 c$ & $0.88 \pm 0.16 b$ & $2.46 \pm 0.42 \mathrm{a}$ & $13.49 \pm 3.25 \mathrm{a}$ & $3.85 \pm 0.92 c$ & $9.48 \pm 1.73 b$ \\
\hline $\mathrm{S}$ & $0.94 \pm 0.02 b$ & $0.96 \pm 0.02 b$ & $1.35 \pm 0.05 \mathrm{a}$ & $22.51 \pm 7.13 a$ & $4.30 \pm 1.18 b$ & $5.22 \pm 0.67 b$ \\
\hline B & $0.01 \pm 0.00 \mathrm{c}$ & $0.01 \pm 0.00 \mathrm{~b}$ & $0.04 \pm 0.00 \mathrm{a}$ & $0.18 \pm 0.07 \mathrm{a}$ & $0.05 \pm 0.02 b$ & $0.16 \pm 0.01 \mathrm{a}$ \\
\hline $\mathrm{Cu}$ & $0.01 \pm 0.00 \mathrm{a}$ & $0.01 \pm 0.00 \mathrm{a}$ & $0.01 \pm 0.00 \mathrm{a}$ & $0.12 \pm 0.03 a$ & $0.02 \pm 0.01 \mathrm{~b}$ & $0.02 \pm 0.00 \mathrm{~b}$ \\
\hline $\mathrm{Fe}$ & $0.07 \pm 0.01 \mathrm{c}$ & $0.09 \pm 0.01 b$ & $0.21 \pm 0.03 \mathrm{a}$ & $1.56 \pm 0.46 a$ & $0.41 \pm 0.15 c$ & $0.83 \pm 0.15 b$ \\
\hline Mn & $0.07 \pm 0.03 \mathrm{~b}$ & $0.13 \pm 0.03 a$ & $0.15 \pm 0.04 \mathrm{a}$ & $1.77 \pm 1.08 \mathrm{a}$ & $0.55 \pm 0.09 b$ & $0.60 \pm 0.21 b$ \\
\hline $\mathrm{Zn}$ & $0.01 \pm 0.00 \mathrm{~b}$ & $0.01 \pm 0.00 \mathrm{~b}$ & $0.01 \pm 0.00 \mathrm{a}$ & $0.18 \pm 0.03 a$ & $0.04 \pm 0.01 \mathrm{~b}$ & $0.04 \pm 0.01 b$ \\
\hline
\end{tabular}

The means that do not differ from each other at the 0.05 significance level by Tukey's test are marked with the same letters.

Table 7

Arithmetic mean nutrients export $\left(\mathrm{kg} \mathrm{ha}^{-1}\right)$ for Eucalyptus grandis $\times$ E. urophylla at 2 years old.

\begin{tabular}{|c|c|c|c|c|}
\hline \multirow[t]{2}{*}{ Nutrients } & \multicolumn{2}{|l|}{ Spacing $2.8 \times 0.5 \mathrm{~m}$} & \multicolumn{2}{|c|}{ Spacing $2.8 \times 1.5 \mathrm{~m}$} \\
\hline & Fertilizing level 1 & Fertilizing level 2 & Fertilizing level 1 & Fertilizing level 2 \\
\hline $\mathrm{N}$ & $119.0 \pm 10.7$ & $133.2 \pm 11.6$ & $89.5 \pm 17.1$ & $116.8 \pm 9.0$ \\
\hline $\mathrm{P}$ & $9.3 \pm 0.8$ & $10.7 \pm 0.9$ & $6.4 \pm 1.2$ & $8.0 \pm 0.6$ \\
\hline K & $141.4 \pm 12.7$ & $168.7 \pm 14.7$ & $66.0 \pm 12.6$ & $93.5 \pm 7.2$ \\
\hline $\mathrm{Ca}$ & $190.8 \pm 17.1$ & $225.2 \pm 19.6$ & $129.6 \pm 24.8$ & $157.8 \pm 12.2$ \\
\hline $\mathrm{Mg}$ & $30.0 \pm 2.7$ & $26.0 \pm 2.3$ & $23.0 \pm 4.4$ & $28.1 \pm 2.2$ \\
\hline S & $37.4 \pm 3.4$ & $39.4 \pm 3.4$ & $22.2 \pm 4.2$ & $29.1 \pm 2.2$ \\
\hline B & $0.4 \pm 0.04$ & $0.5 \pm 0.04$ & $0.3 \pm 0.06$ & $0.4 \pm 0.03$ \\
\hline $\mathrm{Cu}$ & $0.2 \pm 0.02$ & $0.2 \pm 0.02$ & $0.1 \pm 0.02$ & $0.2 \pm 0.01$ \\
\hline $\mathrm{Fe}$ & $3.0 \pm 0.27$ & $3.6 \pm 0.32$ & $2.2 \pm 0.41$ & $2.4 \pm 0.19$ \\
\hline Mn & $2.3 \pm 0.21$ & $4.7 \pm 0.41$ & $2.2 \pm 0.42$ & $2.5 \pm 0.19$ \\
\hline $\mathrm{Zn}$ & $0.3 \pm 0.03$ & $0.3 \pm 0.02$ & $0.2 \pm 0.04$ & $0.2 \pm 0.02$ \\
\hline
\end{tabular}

\subsection{Sustainable use of forest biomass}

The NAI index shown in Table 8 evaluates the sustainability of biomass fractions.

The stem had the more efficient use of macronutrients (higher NAI) than branches and finally leaves, demonstrating the high sustainability of woody fractions compared to the leaves. The lower NAI assigned to leaves was due to greater concentration of nutrients and lower production of dry matter biomass.

The NAI results were much higher than those observed by Sochacki et al. [9] for Eucalyptus globulus and Eucalyptus occidentalis at 3 years old, planted in Western Australia. The difference in results can be attributed to weather conditions, which favored the greater productivity and consequently the high NAI values in this work.

Greater NAI results were found for phosphorus, magnesium and sulfur nutrients. As noted by Sochacki et al. [9], this can be explained by the lower concentration of such nutrients in biomass fractions.

Table 8

Nutrient assimilation index - NAI ( $\left.\mathrm{t} \mathrm{DM} \mathrm{kg}{ }^{-1}\right)$ per biomass fraction for Eucalyptus grandis $\times$ E. urophylla, at 2 years old.

\begin{tabular}{llll}
\hline Macronutrients & \multicolumn{2}{l}{ Fractions biomass } \\
\cline { 2 - 4 } & Stem & Branches & Leaves \\
\hline $\mathrm{N}$ & $0.73 \pm 0.05$ & $0.38 \pm 0.05$ & $0.06 \pm 0.01$ \\
$\mathrm{P}$ & $6.37 \pm 0.44$ & $3.53 \pm 0.51$ & $1.10 \pm 0.08$ \\
$\mathrm{~K}$ & $0.32 \pm 0.06$ & $0.24 \pm 0.05$ & $0.17 \pm 0.02$ \\
$\mathrm{Ca}$ & $0.20 \pm 0.02$ & $0.14 \pm 0.01$ & $0.15 \pm 0.02$ \\
$\mathrm{Mg}$ & $1.78 \pm 0.16$ & $1.17 \pm 0.21$ & $0.41 \pm 0.08$ \\
$\mathrm{~S}$ & $1.07 \pm 0.02$ & $1.05 \pm 0.02$ & $0.75 \pm 0.02$ \\
\hline
\end{tabular}

According Guo et al. [8] there should be removal of only the tree parts with high nutrient use efficiency, such as the stem wood, from the site so that fewer nutrients will need to be replaced by use of commercial fertilizers. Achat [21] reported low or non-significant negative impacts on chemical and biochemical soil fertility when branches are exported, but the foliage is left on site.

There is a difficulty in harvest systems of SRC (shown in Fig. 1) when leaves are left on forest soil. These adaptations are costly and can leave the forage harvest system unfeasible. There can be usage of some practical alternatives to reduce the impact environmentally, such as selection of suitable tree species (e.g., preferred lower crown species), use of correct fertilizer amount and managing the forest regrowth. Additional mitigation measures need to be developed by establishing the link between site fertility and the intensity of the impact of removing harvesting residues [21].

The NAI index shown in Table 9 evaluated the sustainability of treatments.

Greater NAI results were also found for spacing $2.8 \times 0.5 \mathrm{~m}$ (higher density planting) than spacing $2.8 \times 1.5 \mathrm{~m}$ (lower density planting). An inverse trend was observed for potassium nutrient that can be influenced by leaves and branches dry matter yield. More influence of the results found was by biomass allocation and dry matter yield than amount of macronutrients per fraction.

Overall, the higher spacing planting with lower fertilizing level was the most sustainable short rotation coppice due to efficient use of nutrients and higher dry matter yield. In contrast, the lower spacing planting with lower fertilizing level was the least sustainable forest system. These results showed that it is possible to manage the density stand and fertilizers to achieve a more sustainable ecosystem.

This is one of the few studies that evaluated the sustainable use of very high-density eucalypt plantations at tropical conditions, 
Table 9

Nutrient assimilation index $-\mathrm{NAI}\left(\mathrm{t} \mathrm{DM} \mathrm{kg}^{-1}\right)$ for Eucalyptus grandis $\times$ E. urophylla, at 2 years old in different conditions of spacing and fertilization.

\begin{tabular}{|c|c|c|c|c|}
\hline \multirow[t]{2}{*}{ Macronutrients } & \multicolumn{2}{|c|}{ Spacing $2.8 \times 0.5 \mathrm{~m}$} & \multicolumn{2}{|l|}{ Spacing $2.8 \times 1.5 \mathrm{~m}$} \\
\hline & Fertilizing level 1 & Fertilizing level 2 & Fertilizing level 1 & Fertilizing level 2 \\
\hline $\mathrm{N}$ & $0.32 \pm 0.03$ & $0.30 \pm 0.03$ & $0.24 \pm 0.03$ & $0.25 \pm 0.02$ \\
\hline $\mathrm{P}$ & $4.09 \pm 0.37$ & $3.70 \pm 0.32$ & $3.44 \pm 0.39$ & $3.72 \pm 0.21$ \\
\hline $\mathrm{K}$ & $0.27 \pm 0.02$ & $0.23 \pm 0.02$ & $0.33 \pm 0.02$ & $0.32 \pm 0.01$ \\
\hline $\mathrm{Ca}$ & $0.20 \pm 0.02$ & $0.18 \pm 0.02$ & $0.17 \pm 0.02$ & $0.19 \pm 0.01$ \\
\hline $\mathrm{Mg}$ & $1.27 \pm 0.11$ & $1.52 \pm 0.13$ & $0.95 \pm 0.16$ & $1.06 \pm 0.09$ \\
\hline S & $1.02 \pm 0.09$ & $1.00 \pm 0.09$ & $0.98 \pm 0.11$ & $1.02 \pm 0.06$ \\
\hline
\end{tabular}

which makes it rather valuable, especially if one considers the large potential of these plantations to supply the demand of future biomass. Further studies have been conducted in different experimental approach and more rotations.

Finally, the modern concept of silviculture aims to produce more forest biomass sustainably and the goals of further studies should reconsider traditional practices and search new alternatives to maintain an efficient energy crop balanced for future decades.

The sustainability of short rotation forest must be studied holistically, considering also, the demand and water use, light-use efficiency and carbon balanced, economic aspects, and other parameters.

\section{Conclusions}

The density planting and fertilization levels had a greater influence on the dry matter yield, energy yield, and nutrient exports. The higher density planting obtained greater values of dry matter and energy yield, respectively $38.9 \mathrm{t} \mathrm{DM} \mathrm{ha}^{-1}$ and $743 \mathrm{GJ} \mathrm{ha}^{-1}$, showing the potential of very high-density eucalypt plantations for energy generation.

Considering the productivity and nutrients export of short rotation coppice of eucalypt, it was concluded that the higher density planting with the lower dose of fertilization is more indicative of sustainable use.

Evaluating the biomass separately, the leaves should be kept on site due to high nutrient content, and just woody biomass should be harvested for bioenergy. The major values of dry matter and energy were found in stem, followed the branches and leaves that were similar statistically.

This paper introduces a new and more sustainable way to work with short rotation forest considering the evaluation of biomass fractions.

\section{Acknowledgments}

The authors would like to thank the Coordination for the Improvement of Higher Education Personnel (CAPES), the Institute of Bioenergy Research (IPBEN) and the Sao Paulo State University (UNESP) - College of Agricultural Sciences (FCA).

\section{References}

[1] M.F. Demirbas, M. Balat, H. Balat, Potential contribution of biomass to the sustainable energy development, Energy Convers. Manag. 50 (2009) 1746-1760.

[2] REN21. Renewables 2014 Global Status Report. Renewable Energy Policy Network for the 21st Century, Paris, 2014, REN21 Secretariat.

[3] H. Haberl, K.H. Erb, F. Krausmann, A. Bondeau, C. Lauk, C. Müller, et al., Global bioenergy potentials from agricultural land in 2050: sensitivity to climate change, diets and yields, Biomass Bioenergy 35 (2011) 4753-4769.

[4] S. Pérez, C.J. Renedo, A. Ortiz, M. Mañana, F. Delgado, C. Tejedor, Energetic density of different forest species of energy crops in Cantabria (Spain), Biomass Bioenergy 35 (2011) 4657-4664.

[5] R.S. Zalesny Jr., M.W. Cunningham, R.B. Hall, J. Mirck, D.L. Rockwood, J.A. Stanturf, et al., Woody biomass from short rotation energy crops, in:
J.Y. Zhu, X. Zhang, X.J. Pan (Eds.), Sustainable Production of Fuels, Chemicals, and Fibers from Forest Biomass, American Chemical Society, Washington DC, 2011, pp. 27-63.

[6] N.S. Christopherson, J.A. Mattson, Mechanization of the operational aspects of short- rotation forestry, Biomass 22 (1) (1990) 123-133.

[7] A. Navarro, M. Mastrorilli, P. Campi, A.D. Palumbo, G. Facciotto, Biomass production of fast growing woody species in a short rotation coppice in Apulia (Italy), in: 20th European Biomass Conference and Exhibition, Annals, Milan, 2012, pp. 422-426.

[8] L.B. Guo, R.E.H. Sims, D.J. Horne, Biomass production and nutrient cycling in Eucalyptus short rotation energy forests in New Zealand. I: biomass and nutrient accumulation, Bioresour. Technol. 85 (2002) 273-283.

[9] S.J. Sochacki, R.J. Harper, K.R.J. Smettem, B. Dell, H. Wu, Evaluating a sustainability index for nutrients in a short rotation energy cropping system, Glob. Ch. Biol. Bioenergy 5 (2013) 315-326.

[10] D.L. Rockford, D.R. Carter, J.A. Stricker, Commercial Tree Crops for Phosphate Mined Lands, Final Report. Publication No. 03-141-225, FIPR, Florida, 2008.

[11] L. Rosso, G. Facciotto, S. Bergante, L. Vietto, G. Nervo, Selection and testing of Populus alba and Salix spp. as bioenergy feedstock: Preliminary results, Appl. Energy 102 (2013) 87-92.

[12] P. Paris, L. Mareschi, M. Sabatti, A. Pisanelli, A. Ecosse, F. Nardin, et al, Comparing hybrid populus clones for SRF across northern Italy after two biennial rotations: survival, growth and yield, Biomass Bioenergy 35 (2011) $1524-1532$.

[13] B. Mola-Yudego, P. Aronssonb, Yield models for commercial willow biomass plantations in Sweden, Biomass Bioenergy 32 (2008) 829-837.

[14] V.H.D. Zuazo, J.A.J. Bocanegra, F.P. Torres, C.R.R. Pleguezuelo, J.R.F. Martínez, Biomass yield potential of Paulownia trees in a semi-arid Mediterranean environment (S Spain), Int. J. Renew. Energy Res. 3 (4) (2013) 789-793.

[15] H. Grünewald, C. Böhm, A. Quinkenstein, P. Grundmann, J. Eberts, G. Wühlisch, Robinia pseudoacacia L.: a lesser known tree species for biomass production, Bioenergy Res. 2 (2009) 123-133.

[16] IBÁ, Statistics of the Brazilian Tree Industry, Report 2015, Brazilian Tree Industry, Brasília, 2015.

[17] J.L. Stape, D. Binkley, M.G. Ryan, S. Fonseca, R.A. Loos, et al., The Brazil Eucalyptus potential productivity project: influence of water, nutrients and stand uniformity on wood production, For. Ecol. Manag. 259 (2010) 1684-1694.

[18] S.P.S. Guerra, E.A. Garcia, K.P. Lanças, M.A. Rezende, R. Spinelli, Heating value of eucalypt wood grown on SRC for energy production, Fuel 137 (2014) 360-363.

[19] R. Spinelli, S. Ward, P. Owende, A harvest and transport cost model for Eucalyptus spp. fast-growing short rotation plantations, Biomass Bioenergy 33 (2009) 1265-1270.

[20] Forest Energy Portal, Illustrations for your presentations and publications, COST- European Cooperation in Science and Technostemy, IEA Bioenergy e project Metsäenergia, 2015. Available on: http://www.forestenergy.org/ pages/images.

21] D.L. Achat C. Deleuze, G. Landmann, N. Pousse J Ranger, L Augusto, Quantifying consequences of removing harvesting residues on forest soils and tree growth - a meta-analysis, For. Ecol. Manag. 348 (2015) 124-141.

[22] J. Hernandez, A. Del Pino, L. Salvo, G. Arrarte, Nutrient export and harvest residue decomposition patterns of a Eucalyptus dunnii Maiden plantation in temperate climate of Uruguay, For. Ecol. Manag. 258 (2009) 92-99.

[23] H.G. Adegbidi, T.A. Volk, E.H. White, L.P. Abrahamson, R.D. Briggs, D.H. Bickelhaupt, Biomass and nutrient removal by willow clones in experimental bioenergy plantations in New York State, Biomass Bioenergy 20 (2001) 399-411.

[24] B.R. Vital, Método de determinação da densidade da madeira (in Portuguese), Bol. Técnico SIF (1) (1984) 1-21.

[25] ASTM E871-82, Standard Test Methods for Moisture Analysis of Particulate Wood Fuels, American Society for Testing and Materials, West Conshohocken, 2006.

[26] ASTM E711-87, Standard Test Methods for Gross Calorific Value of Refusederived Fuel by the Bomb Calorimeter, American Society for Testing and Materials, West Conshohocken, 2004.

[27] E. Malavolta, G.C. Vitti, S.A. Oliveira, Avaliação do estado nutricional das plantas: princípios e aplicações (in Portuguese), Piracicaba, Associação Brasileira para Pesquisa da Potassa e do Fosfato, 1989.

[28] A.L. Bernardo, M.G.F. Reis, G.G. Reis, R.B. Harrison, Effect of spacing on growth 
and biomass distribution in Eucalyptus camaldulensis, E. pellita and E. urophylla plantations in southeastern Brazil, For. Ecol. Manag. 104 (1998) 1-13.

[29] M. González-García, A. Hevia, J. Majada, M. Barrio-Anta, Above-ground biomass estimation at tree and stand level for short rotation plantations of Eucalyptus nitens (Deane \& Maiden) Maiden in Northwest Spain, Biomass Bioenergy 54 (2013) 147-157.

[30] S.J. Sochacki, R.J. Harper, K.J.R. Smettem, Estimation of woody biomass production from a short-rotation bio-energy system in semi-arid Australia, Biomass Bioenergy 31 (2007) 608-616.

[31] J.M.M.Á.P. Moreira, Potential e participação das florestas na matriz energética (in Portuguese), Pesquisa Florestal Brasileira 31 (68) (2011) 363-372.

[32] K. Senelwa, R.E.H. Sims, Fuel characteristics of short rotation forest biomass, Biomass Bioenergy 17 (1999) 127-140.

[33] J. Garstang, A. Weekes, R. Poulter, D. Bartlett, Identification and Characterization of Factors Affecting Losses in the Large-scale, Non-ventilated Bulkstorage of Wood Chips and Development of Best Storage Practices, First Renewables Ltd., London, 2002.

[34] M.A. Brand, G.I.B. Muñiz, Influência da época de colheita da biomassa floresta sobre sua qualidade para a geração de energia (in Portuguese), Sci. For. 38 (88) (2010) 619-628.
[35] E. Eloy, B. Otomar Carron, D. Agostinho da Silva, D. Schmidt, R. Trevisan, A. Behling, E.F. Elli, Influência do espaçamento nas características energéticas de espécies arbóreas em plantios de curta rotação (in Portuguese), Rev. Árvore 38 (3) (2014) 551-559.

[36] R. Kumar, K.K. Pandey, N. Chandrashekar, S. Mohan, Effect of tree-age on calorific value and other fuel properties of Eucalyptus hybrid, J. For. Res. 21 (4) (2010) 514-516

[37] M. Lemenih, T. Bekele, Effect of age on calorific value and some mechanical properties of three Eucalyptus species grown in Ethiopia, Biomass Bioenergy 27 (2004) 223-232.

[38] A.P.G. Schönau, J. Coetzee, Initial spacing, stand density and thinning in Eucalyptus plantations, For. Ecol. Manag. 29 (1989) 245-266.

[39] H. Du, F. Zeng, W. Peng, K. Wang, H. Zhang, L. Liu, T. Song, Carbon storage in a Eucalyptus plantation chronosequence in Southern China, Forests 6 (6) (2015) $1763-1778$

[40] P. McKendry, Energy production from biomass (part 1): overview of biomass, Bioresour. Technol. 83 (2002) 37-46.

[41] A. Merino, M.A. Balboa, R.R. Soalleiro, J.G.Á. González, Nutrient exports under different harvesting regimes in fast-growing forest plantations in southern Europe, For. Ecol. Manag. 207 (2005) 325-339. 